\title{
KAZIMIERZ SIKORA
}

Uniwersytet Jagielloński

ORCID: 0000-0002-5686-1278

\section{OGNIEM I MIECZEM - LEKCJA SZLACHECKIEGO SAVOIR-VIVRE'U}

Artykuł podejmuje próbę przedstawienia wybranych elementów szlacheckiej, sarmackiej etykiety językowej (głównie powitań i pożegnań), pojawiających się w tekście Ogniem i mieczem Henryka Sienkiewicza. Powieść ta jest bardziej pretekstem dla podejmowanych rozważań, aniżeli ich źródłem. Trudno byłoby przy tej okazji obejść się bez słynnej „ważnej Sędziego nauki o grzeczności” szlacheckiej z I Księgi Pana Tadeusza Adama Mickiewicza. Przypomnijmy więc, że wedle tej pouczającej młodych perory: „Grzeczność nie jest nauką łatwą ani małą” - i nie zastąpi jej książkowa nauka, trzeba bowiem by tej szczególnej wiedzy nabyć w szkołach ,uczących żyć z ludźmi i światem”. A

Trzeba się długo uczyć, ażeby nie zbłądzić

I każdemu powinną uczciwość wyrządzić.

Kiedy się człowiek uczy ważyć, jak przystało,

Drugich wiek, urodzenie, cnoty, obyczaje,

Wtenczas i swoją ważność zarazem poznaje (A. Mickiewicz, Pan Tadeusz).

Współczesne badania nad językową etykietą, mające już wieloletnią tradycję (por. np.: Pisarkowa 1979; Ożóg 1990; Marcjanik 1993; 1997; 2001; 2007; Peisert 1991; Tomiczek 1983; Huszcza 2006; 2007) pozwalają lepiej zrozumieć sens tego wywodu. Normy grzeczności pozostają bardzo ważnym elementem obyczajowości i kultury. Obejmują rozmaite wzory zachowań o charakterze powinnościowym, są projekcją ogólnie uznawanego systemu wartości i społecznych oczekiwań w kontaktach międzyludzkich (stąd pozytywne nacechowanie aksjologiczne i funkcja regulacyjna). Nabywane $\mathrm{z}$ wiekiem umiejętności poruszania się $\mathrm{w}$ tym teatrze życia codziennego należą do kompetencji komunikacyjnej i kulturowej każdej Polki i Polaka. Używam tu stworzonej przez Ervinga Goffmana $(2000 ; 2006)$ metafory teatru życia społecznego, by pokazać, że grzecznościowej kodyfikacji i obyczajowej sankcji podlegają jedynie pragmatycznie relewantne sytuacje, dla których wspólnota formułuje pożądane wzorce relacji interpersonalnych (nie ma więc reguł kłótni ani 
pozdrawiania się w publicznej ubikacji - etykieta pozostaje wobec nich obojętna). Znajomość reguł pragmatycznych i szerzej - komunikacyjnych i kulturowych jest podstawowym warunkiem skutecznego użycia danego zwrotu grzecznościowego (lub wykonania takiego niewerbalnego gestu kultury). W przeciwnym razie kończy się ono niepowodzeniem i towarzyskim zgrzytem. Jest to ważna umiejętność społeczna, co pokazuje przykład prof. Marii Peisert z Wrocławia, której cudzoziemscy studenci z letniej szkoły języka polskiego podziękowali kiedyś za lektorat ułożonym na gałązkach świerczyny bukietem kwiatów, związanych ozdobną wstążką z napisem „Ostatnie pożegnanie” (za Marcjanik 2007). Wypada więc zgodzić się z Sędzią, że nie jest to nauka mała ani łatwa, nie wystarczy bowiem opanować repertuaru grzecznościowych funkcji i zwrotów, ale trzeba przede wszystkim posiąść konieczną wiedzę, jak, w jakich okolicznościach, wobec kogo i z jaką intencją się zachować, by uszanować twarz rozmówcy, a i (jak poucza Sędzia) na własnym wizerunku nie ponieść uszczerbku. Czynimy to tym chętniej, że wspólnota zwykle skutecznie utrwala pożądane wzorce zachowań; świadczyć o tym może przysłowie: Niczego się tak człowiek nie naje, jak wstydu. Czego też nigdy nikomu nie wypada życzyć - chyba że w złorzeczeniu i przekleństwie.

Uwagi te, choć ogólnikowe, dają jednak wyobrażenie, jak karkołomnego w istocie zadania podjął się Henryk Sienkiewicz, próbując wskrzesić na kartach Trylogii wraz z dawnym światem kultury szlacheckiej także i staropolską etykietę należącą do samego jądra obyczajowości szlachty polskiej. $Z$ jak skomplikowanym przedsięwzięciem wypadło mu się mierzyć, widać jasno dopiero dziś, dzięki cennej monografii Marka Cybulskiego Obyczaje językowe dawnych Polaków (Cybulski 2003). Dostarczająca zajmującej lektury książka jest poświęcona tzw. formułom werbalnym, realizującym w okresie średniopolskim (od początku wieku XVI - po trzecie ćwierćwiecze wieku XVIII) podstawowe (pierwszorzędne) funkcje grzecznościowe obecne w takich aktach mowy, jak np.: życzenia, kondolencje, powinszowania, toasty, formuły nawiązania kontaktu, wręczania czegoś (por. naści kiełbaskę - Kmicic do kolubryny; nę, przyjmij laskawie), prośby, zaproszenia, powitania, pożegnania itp. Dodajmy dla porządku, że tak ukierunkowanych filologicznie prac spotyka się niewiele, sporym zainteresowaniem za to cieszyły się od dawna (od czasów Aleksandra Brücknera [Brückner 1916] i Jana Łosia [Łoś 1916]) w polskiej nauce formy adresatywne. Tak jest do czasów współczesnych, dysponujemy więc w tym zakresie całkiem już sporą wiedzą (por. np.: Wojtak 1992; 1996; 1999; Cybulski 2003; 2004; 2005; Cybulski, Pawłowska 2010; Bartnicka 1989; Brajerski 1991/1992; 1992; Stone 1989; Rachwałowa 1987; 1992; Golachowska 2007).

Odpowiedź na pytanie, dlaczego ten właśnie okres pozostaje najważniejszy dla pochodzenia polskiej etykiety językowej a także czemu badania koncentrują się na socjolekcie szlacheckim - wydaje się oczywista, ze względu na dominujący wpływ tego wzorca kultury na obyczajowość językową dawnych Polaków. Wyjaśnić też należy, że czasy społeczno-kulturowej i politycznej supremacji tej wyróżnionej społecznie grupy przyniosły powstanie wyrazistego dworsko-rycerskiego modelu grzeczności, wyróżniającego stan szlachecki na równi z niektórymi zjawiskami językowymi (np. porzucenie samogłosek pochylonych i mazurzenia, labializacji, starej tytulatury patriarchalnej, wykania rozmówcy na rzecz honoryfikatywnego Pan/Pani). Mówi się 
dziś z przekonaniem, że polszczyzna ogólna tamtego czasu odzwierciedla ów dwubiegunowy obraz, przyjmujący potencjał innowacyjny służący podkreśleniu stanowej dominacji i odrębności szlachty - w aspekcie okcydentalizacji, ale i orientalizacji języka i kultury (por. Walczak 1991; 1999; 2017). Patrząc z szerszej, europejskiej perspektywy na jednostronny i nasilający się wpływ kultury szlacheckiego dworu na językową etykietę (w kontekście jednoznacznie szlachecko-dworskiego pochodzenia większości zwrotów i zasad grzeczności), można za Romualdem Huszczą szukać analogii w historycznych prawidłowościach rozwoju kulturalnego średniowiecznych społeczeństw stanowych i sformułować sui generis prawo dziedziczenia etykiety jako atrakcyjnego, bo nobilitującego społecznie warstwy upośledzone, składnika kultury tracących na znaczeniu elit. W całej Europie dochodziło bowiem do regularnego procesu demokratyzacji etykiety dworskiej do roli standardowego wzorca kontaktów towarzyskich (por. Huszcza 2006: 22; Łaziński 2006; Pianka 2010, Sikora 2010). Jak pisałem w innym miejscu: „Ta swoista «językowa kariera» różnych pierwotnie elitarnych zwrotów wszędzie jest pochodną nobilitującej społecznie wartości tych form i dążenia upośledzonych grup społecznych do osiągnięcia równoprawnego statusu w społeczeństwie" (Sikora 2013: 288).

Jeśli odłożymy na bok fałszywe przesłanki ideologiczne, nic nie stoi na przeszkodzie, by uznać pozytywną wartość takich zmian w kulturze i obyczaju towarzyskim, a nawet dostrzec pewien walor kulturotwórczy kryjący się za wpływem arystokratyczno-dworskiego modelu grzeczności na zwyczaje językowe Polaków. Jak widać, nie zgadzam się w tej mierze z A. Brücknerem, który w owym upowszechniającym się sposobie tytułowania innych per PAN/PANI widział li tylko kolejną kartę z dziejów polskiej (i ludzkiej) próżności (Brückner 1916), a nie przejaw faktycznej demokratyzacji stosunków społecznych.

Potrzeby mojego artykułu wymagają podkreślenia, jak wiele polska obyczajowość i językowa grzeczność zawdzięcza tamtym, wydawałoby tak odległym czasom kultury szlacheckiej. Najłatwiej to uczynić przez objaśnienie/przypomnienie pochodzenia wybranych zwrotów grzecznościowych należących dziś do jej podstawowego repertuaru. Wspomniana książka M. Cybulskiego (2003) przekonuje także o tym, jak wiele rozmaitych grzecznościowych zwrotów XVI- i XVII-wiecznych przeszło długą i interesującą drogę rozwoju, nim znalazło swoje poczesne miejsce we współczesnej polszczyźnie. Spośród licznych przykładów, zajmujących uwagę zarówno lingwisty, jak i historyka kultury, dla lepszej orientacji w temacie warto tu przywołać choćby kilka, por. np.:

a) polisemiczność polskiego performatywnego proszę, należącego do podstawowych „słów-zaklęć” polskiej grzeczności (proszę-dziękuję-przepraszam). Ma ono postać jawnego performatywu, co jednoznacznie wskazuje na motywację pragmatycznojęzykową. Niektóre opracowania słownikowe, wyróżniające skrupulatniej kategorie formalnogramatyczne leksemów (np. Dunaj [red.] 1996), wyróżniają nawet 5-6 znaczeń tego wykrzyknika (pod wieloma względami przypominającym niemieckie grzecznościowe bitte, np.: bitte schön; ja bitte; bitte, die Sache verhält sich ganz anderes). Pytanie, jak powstała tak bogata polisemia obciążonego funkcją grzecznościową elementu, jest fascynujące zwłaszcza w perspektywie kulturowo-historycznej. Znajdujemy na nie odpowiedź, śledząc dawne, 
obowiązujące w rozmowie osób pozostających w nierównorzędnych relacjach towarzyskich, formuły etykiety, które uległy leksykalizacji i stały się semantycznie nieprzejrzyste. Warto uciec się tu do znakomitego przykładu „grzecznościowej rozmowy profesora ze studentem", którą przeniósł w odległe czasy XVII wieku M. Cybulski (2003: 254):

- Prosze pana ( $\leftarrow$ Proszę taski WPana 'proszę o okazanie mi pańskiej łaski’), czy mógłby Pan przynieść kredę? (dawniej nie było prośby w trybie pytajnym, ,rekordem” mowy był tryb warunkowy)

- Proszę bardzo ( $\leftarrow$ Prosze przyjąć moje chęci, ustugi itp.)

Przychodzi, daje:

- Proszę ( $\leftarrow$ Proszę przyjąć do rąk swoich...)

- Dziękuję.

- Proszę ( $\leftarrow$ Proszę okazyj do dalszych moich ustug.);

b) rozmaite zwroty obiegowe (powitania, pozdrowienia, podziękowania itp.):

\section{Proszę łaski WPana}

$\rightarrow$ Proszę pana! [wykrzyknik adresatywny; rytualizm fatyczny]

Bóg (ci/WPanu) zdarz (daj) dobry dzień/ dobry wieczór/ dobrą noc.

$\rightarrow$ Dzień dobry! [powitanie]

Czołem biję za cześć (WPana)

$\rightarrow$ Cześć! [powitanie/pożegnanie]

Czołem biję (WPanu)

$\rightarrow$ Czolem! [powitanie]

Daj (ci/WPanu) Bóg wszystkiego dobrego/najlepszego

$\rightarrow$ Wszystkiego najlepszego! [życzenia]

Oddaję (składam, czynię itp.) dzięki

$\rightarrow$ Dzięki! [podziękowanie]

Chętnie stawię się do usług.

$\rightarrow$ Chętnie! [przyjęcie propozycji]

Zamykając ten poboczny wątek rozważań, warto zwrócić uwagę na to, że Henryk Sienkiewicz tak ugruntowanej wiedzy nie miał, czerpiąc ją głównie ze źródeł pamiętnikarskich i rodzinnej tradycji (por. np. Bujnicki 1981; 1996). Dysponując nią współcześnie, odsunąć od siebie przecież musimy pokusę uruchomienia w analizie tekstu Ogniem i mieczem trybu recenzenckiego i wyszukiwania rzeczywistych bądź potencjalnych niedostatków odwzorowania dawnych zwyczajów językowych przez autora. Traktowanie stylizacji językowej w tych kategoriach byłoby naukowym nadużyciem. Krytycznie także trzeba odnieść się do przekonania, że cała Trylogia przynosi w pełni realistyczną panoramę świata kultury szlacheckiej, stanowi swoiste źródło wiedzy o tamtych, bohaterskich czasach. Wystarczy tu nadmienić, że tak chętnie używane przez Zagłobę słowo kiep miało podówczas bardzo wulgarne znaczenie (stąd eufemistyczne ,cztery litery” i nie chodzi tu o to, co dzisiaj), i nijak nie pasuje np. do przysłowia - Kiep odmawia, gdy nie kiep prosi, użytego na kartach powieści jako przyjęcie propozycji alkoholowego poczęstunku; z niejaką satysfakcją piętnowano u H. Sienkiewicza historyczne i socjologiczne nadużycia, wytykano mu rozmaite anachronizmy. Dziś bez trudu - wyposażeni w inwentarz rozmaitych grzecznościowych zwrotów - moglibyśmy dołączyć do grona tych 
uczonych Zoilów, zbrojnych w mędrca szkiełko i oko. Tytułową lekcję wypada więc rozumieć szerzej, jako przywołanie pewnego wyobrażenia (zmitologizowanego na poły), klimatu i realności obyczajowej, w czym H. Sienkiewicz może być bez wątpienia mistrzem i przewodnikiem.

Jak już wspomniano, realnym źródłem wiedzy o regułach użycia grzecznościowych zwrotów mogły być podówczas (1884), u schyłku XIX wieku dla pisarza pamiętniki. Szczególną rolę wśród nich pełni Jan Chryzostom Pasek i jego dzieło (Pasek 1979) ${ }^{1}$. Nietrudno dowieść, że pisarz chętnie w sprawach językowej grzeczności i pragmatyki odwoływał się do jego autorytetu. Tak jest np. w rozmowie pana Michała Wołodyjowskiego z panem Charłampem, co samo w sobie warte jest przytoczenia ${ }^{2}$ i komentarza:

Wołodyjowski wstrzymał konia, bo od razu zrozumiał, że pewnie przyjdzie do jakowegoś zajścia, a lubił z duszy takie rzeczy pan Michał; pan Charłamp zaś zrównał się z nim i z początku nic nie mówił, sapał tylko i wąsami srodze ruszał, widocznie szukając wyrazów; na koniec ozwał się:

- Czołem, czołem, panie dragan!

- Czołem, panie pocztowy ${ }^{3}$ !

- Jak waszmość śmiesz nazywać mnie pocztowym? - pytał zgrzytając zębami pan Charłam mnie, towarzysza i rotmistrza? Ha?

Pan Wołodyjowski począł podrzucać obuszek, który trzymał w ręku, całą uwagę skupiwszy niby na to tylko, by po każdym młyńcu chwytać go za rękojeść - i odrzekł jakby od niechcenia:

- Bo po pętelce nie mogę poznać szarży.

- Waść całemu towarzystwu uwłaczasz, którego nie jesteś godzien.

- A to dlaczego? - pytał z głupia frant Wołodyjowski.

- Bo w cudzoziemskim autoramencie służysz.

- Uspokójże się waćpan - rzecze pan Michał - choć w dragonach służę, przeciem jest towarzysz i to nie lekkiego, ale poważnego znaku pana wojewody - możesz tedy ze mną mówić jak z równym albo jak z lepszym.

\footnotetext{
${ }^{1}$ Cytaty na podstawie tego wydania. Wobec ogólnej dostępności tekstu w zasobach Internetu zrezygnowano z podawania stron tekstu.

${ }^{2}$ Wszystkie cytaty na podstawie wydania powieści pod redakcją Juliana Krzyżanowskiego (Sienkiewicz 1968). Wobec ogólnej dostępności tekstu w zasobach internetowych zrezygnowano z podawania stron powieści.

${ }^{3}$ Pocztowy husarski - żołnierz husarii, werbowany i wyposażany (zwykle w liczbie kilku) przez towarzysza husarskiego, by go wspierać i ochraniać w bitwie. Stąd troska o dobór bitnych i zaufanych ludzi. O ile towarzyszem mógł być tylko szlachcic, to wśród pocztowych byli często chłopi. Dlatego też, mimo iż w bitwie (czego wymagała taktyka) walczyli ramię $\mathrm{w}$ ramię $\mathrm{z}$ towarzyszami i razem przelewali krew, nazywano ich czasem z lekceważeniem pachołkami, czeladnikami, szeregowymi. Pocztowi zamiast skórami lampartów, tygrysów i lwów (co wyróżniało towarzyszy) zbroje zdobili skórami „pospolitych” niedźwiedzi i wilków. Pan Charłamp jest towarzyszem i rotmistrzem (dowódcą chorągwi husarskiej autoramentu narodowego), to stopień wyżej od pana Skrzetuskiego, który był porucznikiem (nominalnie w randze zastępcy rotmistrza - polskiej chorągwi rodowej księcia wojewody ruskiego J. Wiśniowieckiego). Pan Wołodyjowski jest porucznikiem dragonów (chorągwi lekkiej jazdy autoramentu cudzoziemskiego), ale jest też towarzyszem w husarskiej chorągwi polskiej wojewody ruskiego. Daje to okazję do wzajemnych uszczypliwości i kpin obu rycerzy z autoramentu formacji i ,szeregowego” Charłampa. Informację zestawiono głównie na podstawie książek Radosława Sikory (Sikora 2015 i 2019) oraz albumu Radosława Sikory i Radosława Szleszyńskiego Husaria Rzeczypospolitej (Sikora, Szleszyński 2014).
} 
Dla porównania odpowiedni, cytowany także przez M. Cybulskiego, fragment Pamiętników J.Ch. Paska, pokazujący, jak czuli byli panowie szlachta na wszelkie uchybienia względem form etykiety wartościujących rozmówców pod względem statusu (i pragmatycznej rangi) w obrębie stanu szlacheckiego. Takie naruszenie godności było też groźne z tego względu, że kwitowano się z tych „grzechów” chętnie i z użyciem białej broni, którą każdy nosił przy sobie. Por.:

Jednego czasu przyszedłem przed pokój, przed ten ostatni, gdzie król był. Zastałem go tam; nie było, tylko kilka dworskich. Przyszedłem tedy dobrze podpiły i mówię do owego Mazepy: „Czołem, panie assawuła!"” On też zaraz, jako to była sztuka napuszysta, odpowie: „Czołem, panie kapral"s", z tej racyjej, że mię to Niemcy wartowali w Grodnie. A ja, niewiele myśląc, jak go wytnę pięścią w gębę a potem odskoczę się zaraz. Porwie się on za rękojeść, ja też także; skoczyli: „Stój, stój! król to tu za drzwiami”. Żaden dworski przy nim się nie oponował, bo go też nie bardzo nawidzieli, że to był trochę szalbierz, a do tego kozak, niedawno nobilitowany.

Dla H. Sienkiewicza jest więc opisane przez J.Ch. Paska zdarzenie źródłem inspiracji. Nie kopiuje wszak zajścia, lecz atmosferę, w której ustalano relację pragmatycznej rangi rozmówcy po stroju, ozdobach, postawie, barwach, broni, koniu, geście, towarzystwie, sposobie wysławiania się itp., a wyimaginowana nawet obraza na tym tle była zarzewiem emocjonalnego wybuchu, eskalacji emocji iskrą, która w tak naładowanej negatywną energią atmosferze wywołuje zbrojną konfrontację. Jak celnie rzecz ujmuje M. Cybulski:

Odnosi się wrażenie, że ceremoniał i protokół rządziły wówczas w stosunkach między „panami” tak, jak dziś między suwerennymi, ale nierównymi sobie i zbrojnymi państwami. Toteż należało uważnie odmierzać formy służące nawiązaniu kontaktu i ustaleniu relacji w rozmowach, bo rozmówcy stale się pod tym względem oceniali, a na dyshonor reagowali natychmiast i bardzo emocjonalnie. Emocje i popędy uzewnętrzniano w takich wypadkach gwałtownie i wprost, łatwo wyrażano wrogość, łatwo dochodziło do wyzwisk, np. list „odpowiedni”, tekst bądź co bądź prawny i wpisywany do akt, zawierać mógł obelgi. Pod wpływem silnego uczucia szybko pękały okowy ceremoniału; od etykietalnej sztywności przechodzono do dzikiej agresji (Cybulski 2003: 258).

Podobnych fragmentów w Ogniem i mieczem jest więcej; wielokrotnie też czytelnik doświadcza wrażenia, że za owymi rozmaitymi językowymi dystynkcjami tkwi silnie odczuwana potrzeba wyrażania rozmaitych różnic związanych z funkcjonującymi w tej skomplikowanej, wielonarodowościowej społeczności stanowej, a zwłaszcza przypisanej zajmowanemu przez rozmówcę miejscu w społecznej hierarchii społecznej. Normy językowej grzeczności w dawnej Polsce sankcjonowało więc elitarne społecznie dekorum: określony repertuar form i zwrotów uzależniało od miejsca i rangi w relacjach socjalnych, a także od przynależności narodowej (szlachta polska, ruska, kozacka, tatarska), regionalnej (vide niski status Litwinów

${ }^{4}$ Asawut(a), esaut(a), asaut(a) 'u Kozaków zaporoskich: oficer pozostający pod komendą atamana koszowego, zastępca atamana'. Rangą w przybliżeniu odpowiadał namiestnikowi (zastępcy porucznika) husarskiego, a dzisiejszemu starszemu oficerowi, np. majorowi czy podpułkownikowi. J.Ch. Pasek, mając wybór, świadomie użył więc miana lekceważącego, postponującego (pochodzenie) rozmówcę.

${ }^{5}$ Kapral - w tekście 'dowódca drużyny wojsk cudzoziemskiego autoramentu (najemnych)'. 
i wyśmiewanej szlachty mazowieckiej) oraz środowiskowej. W zasadzie tę sytuację, wymagającą tak zróżnicowanych względem adresata zachowań grzecznościowych lepiej opisywałby termin honoryfikatywność szlachecka. W związku z tym warto nadmienić, że równi sobie bohaterowie Ogniem i mieczem uprawiają w kontaktach interpersonalnych tzw. grzeczność ,na skróty” (formuła adresu z 2 osobą orzeczenia), tak np. ośmiela się mówić Rzędzian do Zagłoby, sam zaś konsekwentnie tytularne Jegomość opatruje czasownikiem w 3 osobie, gdy wypada mu zwracać się do pana Skrzetuskiego (ten zaś bezceremonialnie mówi mu po imieniu, tykając sługę wywodzącego się wszak z ubogiej szlachty).

Nie znaczy to oczywiście, że w dawnej rzeczypospolitej nie funkcjonowały alternatywne konwencje grzecznościowe (np. patriarchalno-agrarny, kozacki czy cudzoziemski model grzeczności), czego liczne świadectwa również skrupulatny w obyczajowym szczególe autor pozostawił w swym dziele, np. zwroty adresatywne ojcze, matko, starszy, wykanie rozmówcy. Umiejętność odnalezienia się w takich wzorcach kultury również należała do komunikacyjnej kompetencji ówczesnego dobrze wychowanego szlachcica, co celnie sportretował w swym dziele H. Sienkiewicz.

Tak rozumiane mistrzostwo ujawnia się także w sposobie przedstawienia tytułowych powitań i pożegnań. Czynię tu jednak zastrzeżenie, że nie idzie tu o repertuar zwrotów, który jest dość ograniczony i odznacza się niejaką schematycznością. $\mathrm{Z}$ braku miejsca skupię się tu na wybranych przykładach, obejmujących zarówno relacje równych, jak i niższych sobie osób.

Dla powitania szlacheckiego w powieści H. Sienkiewicza zasadniczo najbardziej charakterystyczny pozostaje zwrot w starodawnej (używany już w XV wieku), imperatywnej formule: witaj! Warto zwrócić uwagę, że semantyka i drugoosobowa forma zwrotu nie wskazuje na jego performatywną funkcję. Pierwotne znaczenie zgodnie ze Słownikiem etymologicznym języka polskiego Wiesława Borysia (Boryś $2005)$ psł. *vitati to 'przybywać dokądś, przebywać, gościć, znajdować schronienie,

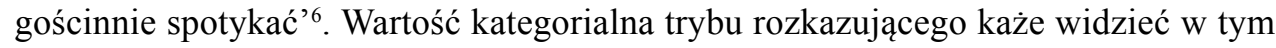
zwrocie rodzaj zaproszenia - życzenia, by odbiorca był, zamieszkał, pozostał na dłużej w miejscu, które wolno interpretować jako przestrzeń własną (orbis interior) nadawcy i jego bliskich. M. Cybulski słusznie argumentuje, że taka postać gramatyczna wskazuje na typową dla polskiej grzeczności językowej (zasada wzajemności i symetryczności zachowań grzecznościowych, por. Marcjanik 1997: 271-275; 2007: 21 i n.) responsywną (reaktywną) postać zwrotu - reakcji, np. na uprzejme powitanie ze strony gościa (por. Cybulski 2003: 18-19). Badania autora wskazują, rzecz istotna, na plebejski charakter i rodowód tej formuły, używanej wobec równych nadawcy lub wyżej postawionych osób. Reguły grzeczności szlacheckiej nakazywały traktowanie równorzędnego rozmówcy z wyszukanym szacunkiem należnym panu i przełożonemu. Ta językowa gra (odzwierciedlanie relacji:

${ }^{6}$ Stąd np. obecność czasownika zawitać (zawitaj w zn. 'przybądź, zostań z nami”) w tytule i w pierwszej zwrotce jednej z najpopularniejszych polskich pieśni maryjnych: Zawitaj, Królowo Różańca Świętego/ Zawitaj, bez zmazy Lilijo. Samo witaj zyskało też swoistą, podniosłą wartość stylistyczną dzięki obecności w wielu tekstach religijnych, zwł. w kolędach (por. Witaj Jezu ukochany). 
nadawca - ,sługa” - odbiorca - „pan”), jak przekonują badania M. Cybulskiego (Cybulski 2003: 269 i n.), ukształtowała zręby sarmackiej etykiety i w ciągu XVI i XVII wieku stała się normą „dworności” i obyczaju towarzyskiego. Można w związku z tym postawić hipotezę, że dość paradoksalnie dzięki temu właśnie mechanizmowi kulturowemu ten stary i ,socjalnie zdeprecjonowany” (Cybulski 2003: 18) zwrot grzecznościowy (podobnie jak prosze łaski WPana $\rightarrow$ prosze pana; zob. Sikora 2013) zdołał przetrwać do naszych czasów, demokratyzacji i egalitaryzacji relacji społecznych. Jak już wyżej wspomniano, od XV wieku zaczęto używać tego czasownika performatywnie, w zn. 'pozdrawiać przy spotkaniu', co wymagało nadania interesującemu nas zwrotowi formy typowej dla formuł sprawczych (por. przysięgam, proszę, dziękuję, przepraszam, obiecuję itp.), ujawniającej działający podmiot grzecznościowego działania (osobę nadawcy). Tym sposobem w języku szlachty (!) pojawiło się innowacyjne, wsparte pozytywnymi konotacjami szlacheckości - witam! Nadal jednak formuła ta była używana przez gospodarza w stosunku do gościa. Można przypuszczać, że nie tylko nowe znaczenie, ale także zmiany o podłożu frekwencyjnym szybko zatarły pierwotny, życzeniowy sens zwrotu. Pragmatyczne reguły użycia (i asocjacje kulturowe) sprawiają, że witam, przysługujące niegdyś szlachcicowi - panu domu i gospodarzowi (stąd jego wyższa ranga pragmatyczna w akcie mowy), naznaczone jest dziś niejaką protekcjonalnością, a witamy i witajcie wynika z oczywistej potrzeby pluralnej postaci zwrotu.

W tekście Ogniem $i$ mieczem można znaleźć poprawnie użyte oba zwroty, jakkolwiek częściej pojawia się pierwotne witaj (w drugim poniższym przykładzie można znaleźć bliskie echa opisanego przez J.Ch. Paska niezmiernie podniosłego powitania 2 lipca 1660 roku, niczym zbawiciela, zwycięskiego wojewody ruskiego Stefana Czarnieckiego, które zgotowali mu uratowani w ostatniej chwili z rosyjskiego oblężenia mieszkańcy Lachowicz), por.:

Witaj waszmość! - rzekł pan Skrzetuski [do pana Zagłoby], gdy szlachcic ukazał się we drzwiach izby. - Czy mnie sobie przypominasz?

Żołnierze [z przybyłych do Zbaraża chorągwi pospolitego ruszenia] z krzykiem garnęli się do niego, padali przed nim na kolana wołając: „Witaj, wodzu niezwyciężony! Herkulesie słowieński! Do gardła stać przy tobie będziem!”- on zaś odpowiadał: „Czołem waszmościom! Na Chrystusowym my wszyscy ordynansie, a moja szarża za niska, bym był szafarzem krwi waszmościów!" - i wracał do siebie, od ludzi uciekał, w samotności z myślami się łamiąc.

- Jako syna cię witam, gdyż tak myślałem, iż cię już nie ujrzę więcej. Znieśże mężnie twoje brzemię i na to pamiętaj, że tysiące będziesz miał towarzyszów w nieszczęściu, którzy potracą żony, dzieci, rodziców, krewnych i przyjaciół. [Książę Jeremi Wiśniowiecki pociesza Skrzetuskiego]

Ale od wieści o wzięciu Baru pan Zagłoba sposępniał, stracił humor, werwę i więcej pana strażnika nie odwiedzał. Myślał nawet pan Łaszcz, że gdzieś od wojska ów jowialny szlachcic odjechał, gdy nagle zobaczył go teraz przed sobą. Wyciągnął tedy ku niemu rękę i rzekł: Witamże waćpana. Czemu to do mnie nie zajdziesz? Co porabiasz? - Panu Skrzetuskiemu towarzyszę - odparł posępnie szlachcic.

Innym, chętnie stosowanym zwrotem powitalnym, oddającym dobrze semantykę solidarności (por. Brown, Gilman 1960) obowiązującą wewnątrz stanu szlacheckiego jest czołem biję (WPanu/Pani). Takie powitanie może być jednocześnie 
(symetryczność) odpowiedzią na nie. Jak pokazują Pamiętniki J.Ch. Paska, pomiędzy szlachtą, zwłaszcza wojskowymi, używano tego bardzo skonwencjonalizowanego zwrotu w postaci zredukowanej zazwyczaj do samego czolem lub czołem $\{k o-$ $\left.m u s^{\prime}\right\}^{7}$. W takim wypadku w prawostronnym sąsiedztwie może się pojawić fraza wokatywna, identyfikująca odbiorcę (jak dzisiejsze wojskowe: Czołem, żołnierze! Czołem, panie generale!). M. Cybulski podkreśla, że ten pierwotnie szlachecki zwrot (zgodnie z prawem dziedziczenia etykiety - dodajmy) szybko stał się w XVII wieku własnością ogółu (Cybulski 2003: 31-32), jednak w powieści H. Sienkiewicza zachowuje on pierwotną społeczną (stanową) ekstensję. Doskonale ukazuje powinnościowy charakter i mocno skonwencjonalizowany sens tej formuły wejście pana Czaplińskiego, podstarościego czechryńskiego do zajazdu w Czechrynie:

Namiestnik nie zdążył odpowiedzieć, bo w tej chwili wszedł do izby jakiś szlachcic z ogromnym hałasem. Drzwiami trzasnął raz i drugi, a spojrzawszy hardo po izbie zawołał: - Czołem waszmościom! Był to człek czterdziestoletni, niski, z twarzą zapalczywą, której to zapalczywości przydawały jeszcze bardziej oczy jakby śliwy na wierzchu głowy siedzące, bystre, ruchliwe - człek widocznie bardzo żywy, wichrowaty i do gniewu skory. - Czolem waszmościom! - powtórzył głośniej i ostrzej, gdy mu zrazu nie odpowiadano. - Czołem, czołem - ozwało się kilka głosów. [...] W Czehrynie nie lubiano go

- dodaje autor.

Tak więc nie dziwi, że jako minimalny znak grzeczności pojawia się także w scenie powitania królewskich posłów przez Chmielnickiego. Wojewoda Kisiel sięga dyplomatycznie do bardziej honorującego rozmówcę zwrotu:

Orszak komisarski zatrzymał się natychmiast, on zaś przyskoczywszy do naczelnych sani, w których jechał wojewoda, patrzył czas jakiś w jego sędziwe oblicze; po czym uchylił trochę kołpaka i rzekł: - Czołem wam, panowie komisary, i tobie, wojewodo! Lepiej było dawniej zacząć ze mną traktaty, kiedy ja był mniejszy i siły własnej nie znał, ale że was korol do mene prisław, tak was wdzięcznym sercem w mojej ziemi przyjmuję... - Witaj, mości hetmanie! - odrzekł Kisiel. - Król jegomość posłał nas, byśmy ci jego łaskę ofiarowali i sprawiedliwość wyrządzili.

Zwrot ten, co podnosi M. Cybulski (Cybulski 2003: 32), obsługuje sferę kontaktów równorzędnych (osób równych sobie); w pewnych warunkach można było tym sposobem witać się także z zamężną kobieta zacnego rodu i liczącej się pozycji, co tak sportretował Sienkiewicz w rozmowie Bohuna z kniahinią Kurcewiczową:

Kniaziówna cofnęła się nagle w głąb kolaski. - Czołem wam, kniahini, i wam, kniaziówno Heleno! - rzekł piąty jeździec. - Bohun! - mówiła stara. - Od pułku przybyłeś, sokole? A z teorbanem? Witajże, witaj! Hej, synkowie! Prosiłam już ichmościów panów na nocleg do Rozłogów, a teraz wy im się pokłońcie! Gość w dom, Bóg w dom! Bądźcież ichmościowie na nasz dom łaskawi.

Demokratyzacja tej formuły powitalnej (w tekście scenicznym z 1729 roku tak wita się szlachcic ze swą kochanką - chłopką; za Cybulski 2003: 32) nie jest

7 Celownikowa fraza obejmuje wyrażenie tytularne (np. waszmości, waszmościom), spełniające rolę semantyczną beneficjenta. 
przeszkodą (Cybulski 2003: 32) w używaniu jej w rozbudowanej postaci, w różnych podniosłych okolicznościach, czemu sprzyja przejrzysta motywacja znaczeniowa i trwałość wyobrażeń uniżonej czołobitności na wzór wschodni, dobrze znanej polskiej kulturze (por. korzyć się, bić pokłony, padać na twarz, lejeć plackiem przed kimś, przypadać komuś do nóg itp.). Taka forma powitania przywołuje też obrazy prostracji jako wyrazu najwyższej czci należnej Bogu w kulturze judeochrześcijańskiej i w islamie. Według A. Brücknera (por. hasło czoło w jego Słowniku etymologicznym języka polskiego) zwyczaje te przyszły do Polski ze Wschodu w XVII wieku. Można zasadnie w ślad za H. Sienkiewiczem przypuszczać, że ową staropolską czołobitnię w literalny sposób praktykowano w stosunkach poddany/sługa: pan.

Wykładnia wartości pragmatycznej zwrotu, znamionująca pierwotną nierówność pozycji społecznej rozmówców ujawnia się dobrze w kontaktach z ludźmi niższego stanu:

- Pójdziemy, gdzie każecie, panie! Wam rozkazywać, nam słuchać! Ale wy nam łaskę zróbcie, jasny rycerzu! Przykażcie panom żołmirom, żeby oni nam zła nie czynili, a sami - wybaczcie prostakom - i ot, bijem czołem pokornie: wypijcie z nami na szczęście uwieńczonym... Wypijcie, wasza miłość, na radość prostym ludziom, jako Bóg i święta ewangelia nakazuje.

W powieści znaleźć można także użycie innego powitalnego zwrotu: kłaniam/ kłaniamy, stanowiącego werbalne odbicie mowy ciała i gestu kultury używanego dla przywitania drugiego i okazania mu szacunku. Kłopot $\mathrm{w}$ tym, że pisarz nie w pełni zdawał sobie sprawę z tego, że jako zwrot grzecznościowy realizujący pragmatyczną funkcję powitania pojawia się on dopiero w XVII wieku. Był więc pisarz fałszywie przekonany, że powitanie tak popularne w jego (i współczesnych nam) czasach musiało mieć swój odpowiednik w języku szlachty XVII-wiecznej. Jakkolwiek zawiodła go intuicja, warto przywołać scenę powitania gości w Rozłogach, domostwie Kurcewiczów (przytyka się gospodarzom brak towarzyskiej ogłady):

Tymczasem młodzi kniaziowie podejmowali gości szczerze i z wielką ochotą, lubo - mało otarci w świecie - czynili to manierą tak niezgrabną, iż namiestnik zaledwie mógł uśmiech powściągnąć. Starszy Symeon mówił:

- Radziśmy waszmościom i wdzięczni za łaskę. Dom nasz - dom wasz, tak też i bądźcie jak u siebie. Kłaniamy panom dobrodziejstwu w niskich progach.

Zastanawia brak w Ogniem i mieczem zwrotów powitalnych typu: służba, służby oddaję/ofiaruję itp. Wiele uwagi poświęca im M. Cybulski (Cybulski 2003: 34-42), dowodząc ich znacznej popularności w bezpośrednich i epistolarnych formach etykiety. Także i ten zwrot, pierwotnie używany wobec osób górujących nad nadawcą statusem społecznym, uległ językowo-kulturowemu przeobrażeniu w sygnał grzeczności (opisana wyżej reguła pan i sługa). Sprzyjała temu także typowa dla powitania, jak się wydaje, uniwersalna w kontaktach międzyludzkich, sytuacja pragmatyczna, przypisująca wyższą rangę rozmówcy, niżli nadawcy, który nawiązywał kontakt (odzywał się pierwszy). Ostatecznie zwroty te stały się w ciągu XVII wieku popularnym (można było tak samo odpowiedzieć witającemu) powitaniem szlacheckim. Raz jeden użył go w swoich Pamiętnikach J.Ch. Pasek: 
Przyjechaliż oni, wnidą do izby: „Służba”. - „Służba”. Prosił siedzieć gospodarz. I pytają mię tedy: „WMMPan skąd jedziesz?” Powiedam: „Z Warszawy”.

Trudno dociec przyczyn takiej autorskiej decyzji. Niewiedzę w tym względzie należałoby raczej wykluczyć.

Pożegnanie, zwłaszcza w wykonaniu bohaterów Ogniem i mieczem, to niekiedy prawdziwe teatrum grzeczności, gdy dla należytego uszanowania rozmówcy jeden zwrot goni drugi, często okraszony rozmaitymi ozdobnikami i powtórzeniami, serdecznymi napomnieniami i życzeniami na drogę. Objawia się w tym dostrzeżona w badaniach M. Cybulskiego (Cybulski 2003, 2005) tendencja do multiplikacji i teatralizacji zwrotów. Tekst utworu zachował dla czytelnika jedną z najbardziej charakterystycznych pod tym względem scen (pożegnanie pana Skrzetuskiego z panem chorążym Zaćwilichowskim w Czechrynie):

Ciemno już było, gdy się znowu zeszli nad brzegiem Taśminowej przystani. Ludzie pana Skrzetuskiego siedzieli już w bajdakach. [...]

- No, szczęśliwej drogi! - mówił chorąży ściskając serdecznie dłoń młodzieńca. - A pilnuj się waść!

- Nie zaniecham niczego. Bóg da, że niedługo się zobaczymy.

- Chyba w Łubniach albo w obozie książęcym.

- To waszmość już koniecznie do księcia?

Zaćwilichowski podniósł ramiona w górę:

- A co mnie? Kiedy wojna, to wojna!

- Zostawajże waszmość w dobrym zdrowiu, mości chorąży.

- Niechże cię Bóg strzeże!

- Vive valeque! - wołał Zagłoba. - A jeśli woda aż do Stambułu waści zaniesie, to kłaniaj się sułtanowi. Albo też: jechał go sęk!... Bardzo to zacny był trójniak!... Brr! jak tu zimno!

- Do widziska!

- Do obaczyska!

- Niech Bóg prowadzi!

Zaskrzypiały wiosła i plusnęły o wodę, bajdaki popłynęły.

Zasadniczo uporządkowane świadectwa funkcjonowania wszystkich tych formuł pożegnalnych $\mathrm{w}$ środowisku szlacheckim (wyjąwszy cudzoziemski cytat) zawiera wielokrotnie tu przywoływana cenna monografia M. Cybulskiego (Cybulski 2003: 54-113). Jak się wydaje, zachowały one semantyczną i funkcjonalną tożsamość także w czasach współczesnych. Z braku miejsca można więc poprzestać na odesłaniu do tej pracy. Trudno obejść się tu jednak bez komentarza. Nie wiadomo skąd, zapewne z przekazywanej rodzinnie tradycji, H. Sienkiewicz zaczerpnął pewną część pojawiających się w powieści zwrotów pożegnalnych. Staropolszczyzna zna np. do ujrzenia (Cybulski 2003: 110; być może jest to relikt życzeniowo-modlitewnej formuły *Boże daj ci zdrowie do ujrzenia). Dalsze modyfikacje zwrotu aż do współczesnej postaci: do widzenia, do zobaczenia są niewątpliwie dziełem późniejszej epoki. Być może autor świadomie stworzył „na wzór ludowy” ekspresywną 
postać zwrotu (do widziska, do obaczyska), by podkreślić serdeczną więź łączącą rozmówców.

Sądzę, że mimo szczupłości miejsca i niedostatku przykładów niniejszy tekst pozostaje dobrym uzasadnieniem dla końcowego wniosku, że etykieta staropolska stanowi jeden z najbardziej wyrazistych rysów odrębności kultury szlacheckiej. Docenienie walorów tego jedynego w swoim rodzaju zjawiska jako środka stylizacji archaizującej w dziele Sienkiewicza jest niewątpliwie świadectwem pisarskiego geniuszu autora Trylogii.

\section{Bibliografia}

Bartnicka B., 1989, Sposoby zwracania się do rozmówców w „,Pamiątkach Soplicy” Henryka Rzewuskiego (Szkic do pragmatyki historycznej), „Poradnik Językowy” 5, s. 276-284.

Boryś W., 2005, Stownik etymologiczny języka polskiego, Kraków.

Brown R., Gilman A., 1960, The Pronouns of Power and Solidarity, w: Style in language, red. T. Sebeok, Cambridge, Mass: Massachusetts Institute of Technology Press, s. 253-276; przedruk w: Readings in the Socjology of. Language, The Hague-Paris 1970, s. $252-276$.

Brajerski T., 1991/1992, Tak zwane zwroty adresatywne w „Krakowiakach i góralach” W. Bogusławskiego, „Roczniki Humanistyczne” 39-40, z. 6, s. 73-80.

Brajerski T., 1992, Ichmość panowie Losiowie matżonkowie, „Język Polski” 72, z. 4-5, s. 247-250 .

Brückner A., 1916, Ty - Wy - Pan. Kartka z dziejów próżności ludzkiej, Kraków.

Bujnicki T., 1981, Sienkiewicz i historia. Studia, Warszawa.

Bujnicki T, 1996, Sienkiewicza „Powieści z lat dawnych”. Studia, Kraków.

Cybulski M., Pawłowska A., 2010, Udział tytulatury standardowej w wołaczowych formach adresatywnych doby średniopolskiej, „Acta Universitatis Lodziensis. Folia Linguistica” 45, s. $29-54$.

Cybulski M., 2003, Obyczaje językowe dawnych Polaków. Formuly werbalne $w$ dobie średniopolskiej, Łódź.

Cybulski M., 2004, Skrócenia $w$ dawnych polskich formach adresatywnych, „Rozprawy Komisji Językowej Łódzkiego Towarzystwa Naukowego" 49, s. 97-110.

Cybulski M., 2005, Obyczaje językowe w dobie średniopolskiej, w: Rozprawy o historii języka polskiego, red. S. Borawski, Zielona Góra, s. 149-211.

Dunaj B. (red.), 1996, Słownik wspótczesnego języka polskiego, Warszawa.

Goffman E., 2000, Człowiek w teatrze życia codziennego, thum. H. Datner-Śpiewak, P. Śpiewak, Warszawa.

Goffman E., 2006, Rytuat interakcyjny, tłum. A. Szulżycka, Warszawa.

Golachowska E., 2007, Formy grzecznościowe w mowie szlachty podlaskiej i grodzieńskiej. Zarys problematyki, „Acta Baltico-Slavica” 31, Warszawa, s. 83-91.

Huszcza R., 2006, Honoryfikatywność. Gramatyka, pragmatyka, typologia, Warszawa.

Huszcza R., 2007, Honoryfikatywny teatr mowy w japońszczyźnie - scena, bohaterowie i rekwizyty grzeczności, w: Grzeczność na krańcach świata, red. M. Marcjanik, Warszawa, s. $127-157$.

Łaziński M., 2006, O panach i paniach. Polskie rzeczowniki tytularne i ich asymetria rodzajowo-ptciowa, Warszawa.

Łoś J., 1916, Od „ty” do „pan”, „Język Polski” 3, s. 1-10. 
Marcjanik M., 1993, Etykieta językowa, w: Encyklopedia kultury polskiej XX wieku, t. 2, Współczesny język polski, red. J. Bartmiński, Wrocław-Lublin, s. 271-281.

Marcjanik M., 1997, Polska grzeczność językowa, Kielce.

Marcjanik M., 2001, Zmiany w etykiecie językowej ostatnich lat XX wieku, w: Zmiany w publicznych zachowaniach językowych, red. J. Bralczyk i K. Musiołek-Kłosińska, Warszawa, s. $79-84$.

Marcjanik M., 2007, Grzeczność w komunikacji językowej, Warszawa.

Ożóg K., 1990, Zwroty grzecznościowe współczesnej polszczyzny mówionej, ZNUJ CMXIII. „Prace Językoznawcze” 98, Kraków.

Pasek J.Ch., 1979, Pamiętniki, wstęp i oprac. W. Czapliński, BN I 62, Wrocław.

Peisert M., 1991, Etykieta językowa i jej wyznaczniki, w: Język a kultura, t. 1. Podstawowe pojęcia i problemy, red. J. Anusiewicz, J. Bartmiński, Wrocław, s. 123-130.

Pianka W., 2010, Historyczne zmiany $w$ systemach adresatywno-honoryfikatywnych $w$ krajach i językach słowiańskich, „Biuletyn Polskiego Towarzystwa Językoznawczego” 66, s. 197$-207$.

Pisarkowa K., 1979, Jak się tytutujemy i zwracamy do drugich, „Język Polski” 59, s. 5-17.

Rachwałowa M., 1987, Formy adresatywne w mowach staropolskich, „Poradnik Językowy” 7, s. 528-535.

Rachwałowa M., 1992, O przyczynach zmian systemu adresatywnego języka polskiego w XIX wieku, w: Język a kultura, t. 6. Polska etykieta językowa, red. J. Anusiewicz, M. Marcjanik, Wrocław, s. 41-49.

Sienkiewicz H., 1968, Ogniem i mieczem, t. 1-2, PIW, Warszawa.

Sikora K., 2010, Grzeczność językowa wsi. Cz. I. System adresatywny, Kraków.

Sikora K., 2013, Od „Prosze taski Pana” do „Proszę Pana”, „Język Polski” 93, z. 4, s. $287-$ -298 .

Sikora R., 2015, Husaria w walce. Chwała polskiego oręża, Warszawa.

Sikora R., 2019, Husaria. Duma polskiego oręża, Kraków.

Sikora R., Szleszyński R., 2014, Husaria Rzeczypospolitej, Warszawa.

Stone G., 1989, Formy adresatywne języka polskiego w osiemnastym wieku, „Język Polski” 69, s. $135-142$.

Tomiczek E., 1983, System adresatywny wspótczesnego języka polskiego i niemieckiego, Wroclaw.

Walczak B., 1991, Między Wschodem a Zachodem (Uwagi o leksyce polskiego języka literackiego), w: Dzieje Lubelszczyzny, t. 6. Między Wschodem a Zachodem, cz. 2. Piśmiennictwo pogranicza, red. R. Łużny i S. Nieznanowski, Warszawa, s. 89-103.

Walczak B., 1999, Zarys dziejów języka polskiego, wyd. 2, Wrocław.

Walczak B., 2017, Chrzest Polski w oczach historyka języka, „Poznańskie Spotkania Językoznawcze" 33, s. 121-130 [DOI: https://doi.org/10.14746/psj.2017.33.10].

Wojtak M., 1992, Wybrane elementy staropolskiej etykiety językowej, w: Język a kultura, t. 6. Polska etykieta językowa, red. J. Anusiewicz, M. Marcjanik, Wrocław, s. 33-40.

Wojtak M., 1996, „O polityce w słowiech”. Formy adresatywne w XVIII wieku, „Język Polski” 76, s. 81-88.

Wojtak M., 1999, Staropolska etykieta językowa jako obraz relacji międzyludzkich (wybrane zagadnienia), w: Przeszłość w językowym obrazie świata, red. A. Pajdzińska, P. Krzyżanowski, Lublin, s. 205-216. 


\section{KAZIMIERZ SIKORA}

\section{Ogniem i mieczem - a lesson on the gentry's savoir-vivre}

\section{Summary}

Polish linguistic courtesy owes a lot to the gentry's culture and courtly culture in general. As research suggests, centuries ago the major and specific norms of Polish etiquette (the special position of women) emerged while the noble and courtly origin of the majority of the contemporary forms of address is beyond doubt. Due to the dominant impact of the aristocratic and courtly model of courtesy on the linguistic habits of contemporary Poles and their ancestors, it seemed interesting and useful to present and describe selected elements of Sarmatism's linguistic etiquette from today's perspective (with special emphasis placed on words of greetings and farewells) included in Henryk Sienkiewicz's famous historical novel, Ogniem i mieczem [With Fire and Sword]. This attempt was also stimulated by the book's cognitive value and the author's impressive knowledge of the Polish gentry in the mid-17th century, obtained as a result of studies of the literary diaries available to him. Therefore, the attempt made to recreate the world of gentry's culture and its model of Old Polish etiquette is not just a product of the author's imagination and it continues to inspire contemporary readers.

Keywords: linguistic etiquette, forms of address, history of language, gentry culture in Poland 